\title{
Biofilm formed on different natural substrates enhances the growth and survival in Macrobrachium rosenbergii (de Man, 1879) juveniles
}

\author{
P. K. JESNA, B. R. PILLAI, NAMITA NAIK AND HARMOHAN PRADHAN \\ ICAR-Central Institute of Freshwater Aquaculture, Kausalyaganga, Bhubaneswar - 751 002, Odisha, India \\ e-mail: bindupillaicifa@gmail.com
}

\begin{abstract}
An experiment of 65 days duration was conducted to study the effect of biofilm formed on different natural substrates at different substratum densities on the growth and survival of juveniles of freshwater prawn Macrobrachium rosenbergii (de Man, 1879). Natural substrates like dried paddy straw and cut grass were evaluated as substratum for biofilm production. The experiment was conducted in fiber glass tanks of 5001 capacity. The study comprised six treatments viz., dried paddy straw at 60 (T1); 120 (T2) and 240 (T3) g tank $\mathrm{k}^{-1}$ and cut grass at 60 (T4) and 120 (T5) g tank ${ }^{-1}$, each with three replicates following a completely randomised design. Prawn juveniles reared without any substratum acted as control. Ten days after the introduction of substratum in the tanks, prawn juveniles $(2.01 \mathrm{~g} \pm 0.37)$ were stocked at a density of $40 \mathrm{~m}^{-3}$. The juveniles were fed with $2 \mathrm{~mm}$ commercial pellet feed (30\% protein) at $5 \%$ of the biomass. No water exchange was done in the treatment tanks whereas in control tanks $50 \%$ water exchange was done once every week. The study revealed significantly $(\mathrm{p}<0.05)$ higher survival rate $(\%)$ in the treatment tanks $(94.4 \pm 9.6,80.5 \pm 12.7,86.1 \pm 12.7,86.1 \pm 4.8$ and $91.6 \pm 8.35$ for treatments T1,

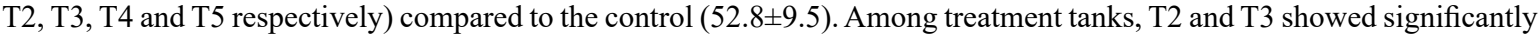
higher $(\mathrm{p}<0.05)$ average daily growth $\left(\mathrm{g} \mathrm{d}^{-1}\right)(0.055 \pm 0.005$ and $0.057 \pm 0.005$ respectively $)$ when compared to other treatments $(0.0367 \pm 0.02$ for $\mathrm{T} 1$ and $0.0373 \pm 0.01$ for $\mathrm{T} 5)$. But the specific growth rate did not show any significant difference among the treated groups including control. Use of biofilm significantly reduced the usage of water (by 2.9 times) compared to control, which is significant considering the predicted water scarcity in future.
\end{abstract}

Keywords: Biofilm, Freshwater prawn, Growth, Macrobrachium rosenbergii, Survival

\section{Introduction}

A biofilm is an assemblage of microbial cells which is irreversibly associated with a surface and enclosed in a matrix of primarily polysaccharide material (Pandey et al., 2014). It may form on a wide variety of surfaces, including living tissues, medical devices, industrial or potable water system pipe or natural aquatic systems. A well-diversified group of organisms such as algae, bacteria, protozoa and arthropods, may be observed in the biofilm assemblage. The biofilm structure depends on the nature of substratum, hydrodynamics of system, nutrient availability, light and grazing capacity of organisms. It has been observed that the introduction of substrata for the development of biofilm in the aquaculture system play a significant role in maintaining water quality (Mridula et al., 2006). The organisms of biofilm may serve as source of single cell protein and are easily harvested by wide size ranges of farmed aquatic species as compared to planktonic organisms in the water column. Biofilms are considered as source of good quality protein $(23-30 \%)$ (Pandey et al., 2014). Microalgae and heterotrophic bacteria present in biofilm are rich source of immune enhancers, growth promoters, bioactive compounds and dietary stimulants which can enhance growth performance of cultured organisms. The substrates also provide shelter and hiding places to cultured organisms. The attached nitrifying bacteria contained in biofilm improve the water quality by lowering ammonia levels in culture systems through nitrification process. Biofilm based low cost technology will help resource poor farmers in generating protein rich food from aquaculture in a sustainable manner (Pandey et al., 2014). Enhancement of water quality and growth performance through biofilm production may give considerable contribution to sustainable fish farming practices. With increasing demand for environment friendly aquaculture, the use of biofilm in aquaculture needs to be promoted as one of the thrust areas for development of aquaculture systems.

The substrate based aquaculture, the concept of biofilm, biocapsules, probiotics and microbial mats are being increasingly recognised in commercial aquaculture (Panigrahi et al., 2015). Earlier studies on use of biofilm revealed the importance of using this technology in aquaculture production systems (Mridula et al., 2006, Katoon et al., 2007; Keshavanath et al., 2012). Keshavanath et al. (2001) evaluated Indian major carp 
(IMC) production with sugarcane bagasse as substrate for periphyton. The results demonstrated that sugarcane bagasse can be successfully used as a substrate for periphyton and maximum total fish production would be achieved at bagasse densities of $21 \mathrm{~kg} 100 \mathrm{~m}^{-2}$ without feeding and $28 \mathrm{~kg} 100 \mathrm{~m}^{-2}$ with feeding. The contribution of epiphytes associated with physical substrates to the nutritional requirements of post-larval shrimp, Penaeus esculentus was determined in high density rearing systems (@ 3000,6000 and 11,000 nos. $\mathrm{m}^{-3}$ ) and was proved to be beneficial as an additional food source for shrimp (Burford et al., 2004).

Macrobrachium rosenbergii (de Man, 1879), is an important species for inland aquaculture in India. Freshwater prawn production in India has increased steadily since mid-nineties and reached a peak of $42,820 \mathrm{t}$ in 2005, but then declined to $7989 \mathrm{t}$ in 2014-15. Efforts are being made to develop a fast growing strain of this species through genetic improvement (Pillai et al., 2011) which would help to increase the production of this species in future. In order to attract prospective farmers to freshwater prawn farming, it is important to develop a low cost culture technology. With this objective, a study was conducted to evaluate the effect of biofilm produced on different natural substrates at different substratum densities on the growth and survival of the freshwater prawn $M$. rosenbergii.

\section{Materials and methods}

The experiment was conducted in the wet laboratory of the freshwater prawn unit of ICAR-Central Institute of Freshwater Aquaculture (ICAR-CIFA), Bhubaneswar. FRP tanks of 5001 capacity were used for the experiment. Continuous and uniform aeration was provided in all the tanks throughout the experimental period. Dried paddy straw and cut grass were evaluated as substrata for biofilm production. The experiment consisted of six treatments such as T1, T2 and T3 stocked with dried paddy straw (a) 60; 120 and $240 \mathrm{~g} \mathrm{tank}^{-1}$ respectively as well as T4 and T5 stocked with cut grass@60 and $120 \mathrm{~g} \mathrm{tank}^{-1}$ respectively. Each treatment had three replicates following a completely randomised design. The bundle of substrates (each weighing $60 \mathrm{~g}$ ) were kept hanging using a rope tied to a pole fitted on top of the tanks in such a way as to keep them immersed in subsurface water. Prawn juveniles reared without any substratum acted as control.

Ten days after introduction of substratum in the tanks, juvenile prawns of average body weight $2.01 \mathrm{~g} \pm 0.37$ were stocked at a density of 40 nos $\mathrm{m}^{-3}$ of water. The juveniles were fed with $2 \mathrm{~mm}$ commercial pellet feed (30\% protein) at $5 \%$ of the biomass, which was divided in to two equal halves and fed at $8.30 \mathrm{hrs}$ in the morning and $15.30 \mathrm{hrs}$ in the evening. The leftover feed was siphoned out daily at $8.00 \mathrm{hrs}$ in the morning and once in a week freshwater was added to the tanks to make up the water lost during daily siphoning to remove the leftover feed and faecal matter. Since the total ammonia content in control tanks was observed to be comparatively high along with mortality of prawns, $50 \%$ water exchange was carried out once in a week in control tanks. Water quality parameters such as temperature, dissolved oxygen, ammonia and $\mathrm{pH}$ were analysed once in five days interval following standard methods (APHA, 1998). Body length and body weight of all experimental animals were measured at fortnightly intervals. After 65 days, all the surviving prawns were sampled for final data collection. The data were statistically analysed by one way ANOVA, using the statistical tool SPSS 16 version.

\section{Results and discussion}

The results of analysis of water quality parameters are presented in Table 1 . The water temperature ranged from 21.1 to $21.4^{\circ} \mathrm{C}$, which is lower than the optimal water temperature $\left(26-31^{\circ} \mathrm{C}\right)$ for prawn culture (New and Valenty, 2009). All the other water quality parameters recorded were within the optimum range for prawn culture. Even though lower average dissolved oxygen value was observed in control tanks, it was not significantly $(p>0.05)$ different from the treatment groups. The $\mathrm{pH}$ values ranged from 7.97 to 8.03 during the study period. It was observed that total ammonia nitrogen in the control tanks was significantly higher $(\mathrm{p}<0.05)$ compared to the treatment tanks throughout the period of the experiment with peak values $\left(0.059 \pm 0.01^{\mathrm{b}}\right)$ recorded during the $3^{\text {rd }}$ week. Whereas the ammonia content in the treatment tanks did not show comparable difference among the treatments (Fig. 1).

Table 1 . Water quality parameters of different treatment tanks (Mean $\pm \mathrm{SE}$ )

\begin{tabular}{lllll}
\hline Treatment & Temperature $\left({ }^{\circ} \mathrm{C}\right)$ & Dissolved oxygen $\left(\mathrm{mg} \mathrm{l}^{-1}\right)$ & Alkalinity $\left(\mathrm{mg} \mathrm{l}^{-1}\right)$ & $\mathrm{pH}$ \\
\hline T1 & $21.4 \pm 0.22$ & $8.10 \pm 0.06$ & $82.14 \pm 0.89$ & $7.98 \pm 0.02$ \\
T2 & $21.2 \pm 0.23$ & $8.22 \pm 0.06$ & $80.75 \pm 0.88$ & $7.96 \pm 0.02$ \\
T3 & $21.2 \pm 0.23$ & $8.11 \pm 0.06$ & $80.58 \pm 1.00$ & $7.97 \pm 0.01$ \\
T4 & $21.2 \pm 0.23$ & $8.13 \pm 0.05$ & $80.56 \pm 0.83$ & $7.99 \pm 0.01$ \\
T5 & $21.2 \pm 0.24$ & $8.12 \pm 0.06$ & $79.31 \pm 0.087$ & $8.03 \pm 0.06$ \\
C & $21.3 \pm 0.23$ & $7.99 \pm 0.04$ & $79.42 \pm 0.09$ & $7.96 \pm 0.02$ \\
\hline
\end{tabular}




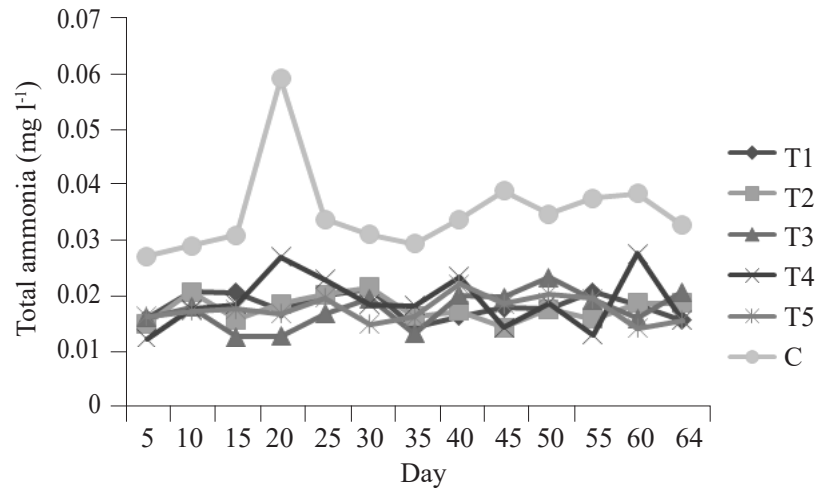

Fig. 1. Variations in total ammonia in different treatment and control tanks during the experimental period

The lower levels of ammonia nitrogen in the treatment tanks may be due to the nitrification processes facilitated by the microbial biomass attached to the plant substratum in the tanks. Li et al. (2017) also reported that the provision of artificial substrata effectively reduced the concentrations of total nitrogen in freshwater aquaculture pond.

The study revealed significantly $(\mathrm{p}<0.05)$ higher survival rate $(\%)$ in the treatment tanks $(94.4 \pm 5.57$, $80.7 \pm 7.35, \quad 86.1 \pm 7.31, \quad 86.1 \pm 2.8$ and $91.8 \pm 4.82$ for treatments $\mathrm{T} 1, \mathrm{~T} 2, \mathrm{~T} 3, \mathrm{~T} 4$ and $\mathrm{T} 5$ respectively) compared to the control (52.9 \pm 5.53$)$ (Table 2). Among treatment tanks, T2 and T3 showed significantly higher $(\mathrm{p}<0.05)$ average daily growth $\left(\mathrm{g} \mathrm{d}^{-1}\right)(0.055 \pm 0.003$ and $0.057 \pm 0.003$ respectively) when compared to other treatments $(0.037 \pm 0.009$ for $\mathrm{T} 1$ and $0.037 \pm 0.006$ for T5) (Table 2). But the specific growth rate (SGR) did not show any significant difference among the treated groups including control $(1.10 \pm 0.28,1.35 \pm 0.14$, $1.49 \pm 0.31,1.46 \pm 0.07,1.23 \pm 0.15,1.19 \pm 0.04$ for $\mathrm{T} 1, \mathrm{~T} 2$, T3, T4, T5 and control respectively). The final weight of the prawns in T2 $(5.63 \pm 0.12)$ and T3 $(5.69 \pm 0.08)$ was significantly higher than $\mathrm{T} 1(4.49 \pm 0.05), \mathrm{T} 5(4.50 \pm 0.02)$ and control (4.55 \pm 0.18$)$. The lower survival rate in control ( $\sim 30-40 \%$ lower than that of treatment) and the resultant lower density might be the reason for lack of significant difference in growth rate between treatment and control as higher density was reported to have significant negative effect on growth rate of $M$. rosenbergii (Valenti et al., 1993, Siddiqui et al., 1997; Paul et al., 2016). Schveitzer et al. (2013) reported an increase in shrimp biomass production in Litopenaeus vannamei culture systems in presence of substrates.

Water exchange is a routine practice in aquaculture. Hopkins et al. (1993) reported that a combination of higher stocking density and no water exchange resulted in mass mortalities of cultured shrimp owing to poor water quality. Microorganisms being nature's original recyclers (Panigrahi et al., 2015) help to retain the water quality in aquaculture production systems through bioremediation of the nitrogenous wastes and thus minimise the requirement of water exchange. In the present study, each treatment tank used 5701 of water for the entire 65 days, which includes 3001 initial filling and 10\% weekly addition to make up the volume lost during cleaning. Whereas each control tanks used 16501 of water for 65 days including 3001 initial filling and 50\% weekly exchange (Fig. 2). This finding is in agreement with that of Veronica et al. (2016) who assessed the contribution of biofilm on water quality and as a food source for the culture of the freshwater shrimp Neocaridina heteropoda. In the present study, it was found that the biofilm grown on all the evaluated substrates helped to maintain good water quality by facilitating the uptake of nitrogen compounds and by the

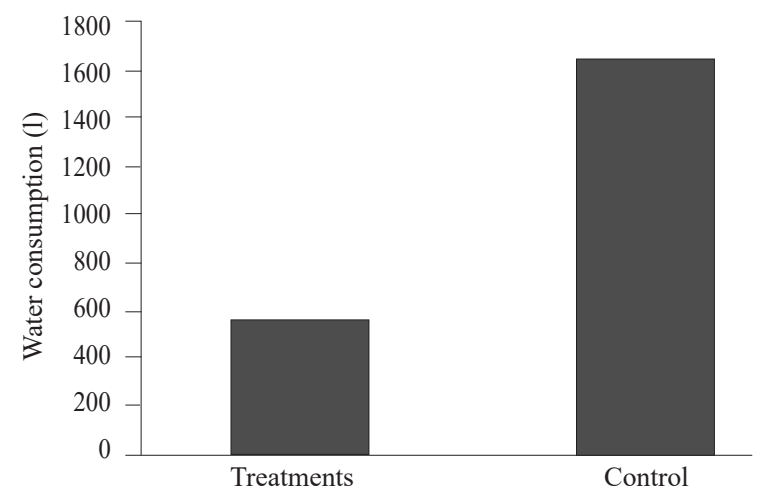

Fig. 2. Total water requirement of treatment tanks and control tanks during the culture period

Table 2. Survival (\%), average daily growth $\left(\mathrm{g} \mathrm{d}^{-1}\right)$ and specific growth rate (\%) of $M$. rosenbergii in different treatment tanks

\begin{tabular}{lllll}
\hline Treatment & Survival (\%) & Average daily growth $(\mathrm{g})$ & Specific growth rate $(\%)$ & Final weight $(\mathrm{g})$ \\
\hline T1 & $94.43 \pm 5.57^{\mathrm{b}}$ & $0.037 \pm 0.009^{\mathrm{a}}$ & $1.10 \pm .28^{\mathrm{a}}$ & $4.49 \pm 0.05^{\mathrm{a}}$ \\
T2 & $80.57 \pm 7.35^{\mathrm{b}}$ & $0.055 \pm 0.003^{\mathrm{b}}$ & $1.35 \pm 0.14^{\mathrm{a}}$ & $5.63 \pm 0.12^{\mathrm{b}}$ \\
T3 & $86.1 \pm 7.31^{\mathrm{b}}$ & $0.057 \pm 0.003^{\mathrm{b}}$ & $1.49 \pm 0.31^{\mathrm{a}}$ & $5.69 \pm 0.08^{\mathrm{b}}$ \\
T4 & $86.10 \pm 2.80^{\mathrm{b}}$ & $0.044 \pm 0.007^{\mathrm{ab}}$ & $1.46 \pm 0.07^{\mathrm{a}}$ & $5.03 \pm 0.04^{\mathrm{ab}}$ \\
T5 & $91.67 \pm 4.82^{\mathrm{b}}$ & $0.037 \pm 0.006^{\mathrm{a}}$ & $1.23 \pm 0.16^{\mathrm{a}}$ & $4.50 \pm 0.02^{\mathrm{a}}$ \\
C & $52.77 \pm 5.53^{\mathrm{a}}$ & $0.040 \pm 0.004^{\mathrm{ab}}$ & $1.19 \pm 0.04^{\mathrm{a}}$ & $4.55 \pm 0.18^{\mathrm{a}}$ \\
\hline
\end{tabular}

\# All values are $($ Mean \pm SE). Means in the same column with different superscript are significantly different $(\mathrm{p}<0.05)$ 
production of high levels of dissolved oxygen associated with the proliferation of autotrophic microorganisms.

The present study revealed that biofilm formed on naturally available substrates such as paddy straw and dry grass provided in a tank based system can improve the survival rate and growth in $M$. rosenbergii juveniles by improving the water quality of the system and also by providing additional nutrition from the biofilm. It was also observed that by using biofilm for water quality control, water requirement can be reduced by 2.9 times which is significant considering the predicted water scarcity in future. As freshwater prawns are very sensitive to low dissolved oxygen (DO) levels, many monoculture farmers have suffered loss of stock due to low DO associated mass mortality. Most of the prawn farmers usually resort to frequent water exchange to maintain water quality in ponds. This leads to wastage of water and increase in production cost due to use of fuel for water exchange. Hence any low cost strategy that helps to improve the water quality, thereby leading to good survival and growth of farmed prawns would be beneficial to the farmers.

\section{References}

APHA-AWWA-WEF 1998. Standard methods for the examination of water and waste water, $20^{\text {th }}$ edn. American Public Health Association, American Water Works Association, Water Environment Federation, Washington D. C., USA, 1193 pp.

Burford, M. A., Sellars, M. J., Arnold, S. J., Keys, S. J., Crocos, P. J. and Preston, N. P. 2004. Contribution of the natural biota associated with substrates to the nutritional requirements of the post-larval shrimp, Penaeus esculentus (Haswell) in high density rearing systems. Aquac. Res., 35: 508-515.

Hopkins, J. S., Hamilton, R. D., Sandier, P. A., Browdy, C. L. and Stokes, A. D. 1993. Effect of water exchange rate on production, water quality, effluent characteristics and nitrogen budgets of intensive shrimp ponds. J. World Aquac. Soc., 24(3): 304-320.

Keshavanath, P., Ramesh, T. J., Gangadhar, B., Beveridge, M. C. M., Van Dam, A. A. and Verdegem, M. C. J. 2001. On-farm evaluation of Indian major carp production with sugarcane bagasse as substrate for periphyton. Asian Fish. Sci., 14: 367-376.

Keshavanath, P., Manissery, J. K., Bhat, A. G. and Gangadhar, B. 2012. Evaluation of four biodegradable substrates for periphyton and fish production. J. Appl. Aquac., 24: 2012.

Khatoon, H., Yusoff, F. M., Banerjee, S., Shariff, M. and Mohamed, S. 2007. Use of periphytic cyanobacterium and mixed diatoms coated substrates for improving water quality, survival and growth of Penaeus monodon post-larvae. Aquaculture, 271: 196-205.
Li, Z., Che, J., Xie, J., Wang, G., Yu, E., Xia, Y., Yu, D. and Zhang, K. 2017. Microbial succession in biofilms growing on artificial substratum in subtropical freshwater aquaculture ponds. FEMS Microbiol. Lett., 364(4). doi: 10.1093/femsle/fnx017.

Mridula, R. M., Manissery, J. K., Rajesh, K. M., Keshavanath, P., Shankar, K. M. and Nandeesha, M. C. 2006. Effect of microbial biofilm in the nursery phase of mrigal, Cirrhinus mrigala. J. Indian Fish. Ass., 33: 103-112.

New, M. B. and Valenti, W. C. 2009. Freshwater prawn culture: the farming of Macrobrachium rosenbergii. Blackwell Science, Oxford, England, 512 pp.

Pandey, P. K., Bharti, V. and Kumar, K. 2014. Biofilm in aquaculture production. Afr. J. Microbiol. Res., 8: 1434-1443.

Panigrahi, A., Mohapatra, A. and Panigrahi, A. 2015. Bioremediation: An environmental friendly approach for sustainable aquaculture. ICAR-Central Institute of Brackishwater Aquaculture, $10 \mathrm{pp}$.

Pillai, B. R., Mahapatra, K. D., Ponzoni, R. W., Sahoo, L., Lalrinsanga, P. L., Nguyen, N. H., Mohanty, S., Sahu, S., Vijaykumar, Sahu, S., Khaw, H. L., Patra, G., Patnaik, S. and Rath, S. C. 2011. Genetic evaluation of a complete diallel cross involving three populations of freshwater prawn (Macrobrachium rosenbergii) from different geographical regions of India. Aquaculture, 319: 347-354.

Paul, P., Rahman, M., Hossain, M. M., Islam, M. S., Mondalm S. and Haq, M. M. 2016. Effect of stocking density on the growth and production of freshwater prawn (Macrobrachium rosenbergii). Int. J. Fish Aquac. Sci., 6(1): $77-86$

Schveitzer, R., Arantes, R., Baloi, M. F., Costodio, P. S., Arana, L. V., Seiffert, W. Q. and Andreatta, E. R. 2013. Use of artificial substrates in the culture of Litopenaeus vannamei (biofloc system) at different stocking densities: Effects on microbial activity, water quality and production rates. Aquacult. Eng., 54: 93-103.

Siddiqui, A. O., Hafedh, Y. S., Harbi, A. H. and Ali, S. A 1997. Effects of stocking density and monosex culture of freshwater prawn Macrobrachium rosenbergii on growth and production in concrete tanks in Saudi Arabia. J. World Aquac. Soc., 28(1): 106-112.

Valenti, W. C., Cardoso de Mello, J. T. and Castagnolli, N. 1993. The effect of stocking density on Macrobrachium rosenbergii (De Man) growth curves in earthen ponds (Crustacea, Palaemonidae). Rev. Bras. Zool., 10(3).

Veronica, E. V., Marciano, A., Iriel, A., Laura, S. and Greco, L. 2016. Assessment of a biofilm-based culture system within zero water exchange on water quality and on survival and growth of the freshwater shrimp Neocaridina heteropoda heteropoda. Aquac. Res., 47(8): 2528-2542. 